\title{
At The Cross Of History Of Archives And Archaeology: M.E. Masson's Personal Archive Fund As An Important Historical Source
}

Sherzodjon Shokirjonovich Choriev

PhD, Associate Professor At The National University Of Uzbekistan, Tashkent, Uzbekistan

\section{ABSTRACT}

This article is devoted to the historical source analysis of the personal fund R-2773, kept in the National Archives of Uzbekistan by archaeologist Masson Mikhail Evgenevich. The article also analyzes a number of research papers stored in the private fund, a scientific article on the organization of the Department of Archeology at the Central Asian State University (now the National University of Uzbekistan), the educational process, the department's cooperation. In particular, the article analyzes some of the scholar's scientific work in the field of archives.

\section{KEYWORDS}

National Archive of Uzbekistan, EM Masson, archeology, department, expedition, report, archive, fund, Nisa, Parthia, collection, document.

\section{INTRODUCTION}

There is a lot of news today about the development of various disciplines, new directions or research in the field of science. In particular, the Government of the Republic of Uzbekistan pays special attention to the fields of archiving and archeology [1]. It is the development of archeology that allows us to clarify a lot of information about the history of ancient archival work in Central Asia and Uzbekistan. In particular, many scientific works in the personal fund of archaeologist Masson Mikhail Evgenevich, preserved in the National Archives of Uzbekistan, are devoted to the development of archeology in Central Asia, the analysis of many archaeological studies. ME Masson was awarded the title of 
Doctor of Archeology without defense and in 1938-1939 was invited to the Central Asian State University (now the National University of Uzbekistan) to give lectures on archeology, numismatics. On April 1, 1940 he was appointed head of the Department of Archeology, Faculty of History of the same university. During his career, the scientist conducted research in the field of archeology in Central Asia and Uzbekistan in many areas of archeology, historical linguistics, historical reconstruction, topography, paleoanthology, zoology and others.

However, it should be noted that some of the research work of the scientist is distinguished by the fact that it analyzes the archaeological sources of some economic archives that exist in Central Asia.

\section{MAIN PART}

\section{Source description of the personal fund Nowadays,}

M.E. Masson's personal fund is stored in the National Archive of Uzbekistan in the fund R2773. In 1886, archival documents of E.M. Masson for 1934-1983 were submitted by his wife G.A. Pugachenkova. In 1987, after his death, the second part of the documents from 1873-1982 was also transferred to the archive.

M.E Masson's personal fund R-2773, kept in the National Archives of Uzbekistan, has a single inventory of 1246 cases. Documents stored in the fund, such as monographs and published works, articles, essays, reports and abstracts, scientific works published under his editorship, reports on the Archaeological Expedition of Southern Turkmenistan are divided into a total of 12 sections.
The fund also contains important historical scientific documents on the history of archeology, such as monographs, historical essays, scientific articles, reports of archaeological expeditions, correspondence with various scientists, photo collections.

Also, the inventory includes a list of abbreviated words. Along with the documents, negative copies of 85 photographic documents from 1958-1959 were presented. As a result of a scientific and technical check of the fund's documents, 128 archival files were destroyed, which belonged to the years 1928-1982.

\section{Brief information about the life and work of M.E. Masson}

The autobiography of Mikhail Evgenievich is also given in the introduction to the inventory of his personal fund. It indicates that Mikhail Evgenievich Masson was born on November 21 (December 4), 1897 in St. Petersburg. M.E. Masson's father worked for many years as a surveyor and topographer in Central Asia. He came to Samarkand when he was 2 years old. In 1912, he took part in the archaeological excavations of Afrasiab, conducted by V.A.Vyatkin. In 1916 he graduated from the Samarkand gymnasium and continued his studies at the Petrograd Polytechnic Institute. In 1917 he entered military service [2].

In 1918 M.E. Masson returned to Samarkand and became the head of the Samarkand Museum. In 1924, in Tashkent, he worked as the head of the archeology department of the Committee for the Protection of Museums, Arts and Historical Monuments of Turkestan (later Uzbekistan). In 1929-36. The Geological Committee conducted a lot of research on the history of mountains, museums, restoration of historical monuments. 
In 1936 he was awarded the title of Doctor of Archeology without protection. In 1938-1939 he was invited to the Central Asian State University (now the National University of Uzbekistan) to give lectures on archeology, numismatics, and on April 1, 1940 he was appointed head of the "Archeology" Department of the History Faculty of the Central Asian State University.

\section{Analysis of the article on the history of the Department of Archeology, Faculty of History of the National University of Uzbekistan}

The 1240th file of the personal fund of E.M. Masson is called "Department of Achaeology of Central Asia SAGU 1940-1960 Article. Typewritten copy with copyright correction " (“Кафедра Ахеологии Средней Азии САГУ 1940-1960 гг. Статья. Машинописьная копия с авторской правкой"). The collection includes an 18-page article which written by an archaeologist on the history of the Department of Archeology of the faculty of History of the National University of Uzbekistan [3]. The collection contains edited articles by E.M. Masson personally and prepared for publication.

According to the article in the case, at the end of 1939, courses on the archeology of Central Asia began at the History faculty of the Central Asian State University.

In 1940, the Department of Archeology officially began its work. In 1941, the department suspended its activities due to the Great Patriotic War, but resumed informal activities. Since 1942, it officially resumed its activities. In 1943, the department was assigned the position of associate professor, and this position was appointed by G.A. Pugachenkova.

In the following years, at the department, Doctor of Geographical Sciences N.G. Malitsky (ethnology and geography of Central Asia), doctor of biological sciences L.V. Oshanin (anthropology and anthropogenesis), doctor of historical sciences A.A. Semenov (Oriental Studies), Doctor of Historical Sciences A. Petrushevsky (Islamic Studies) and others lectured. In 1942-1945. Professor S.N. Zamyatkin taught general archeology and methods of field archaeological research, and Professor V.P. Smirnov - Quaternary geology [4].

With the establishment of the department, special attention was paid to scientific researchs. Initially, the "Student Scientific Archaeological Circle" was established, and students participated in regular archeological expeditions every year. Primarily, two students took part in an expedition to a historical monument of the 15th century in Samarkand, known as "Ishratkhona", which carried out archaeological excavations, excavations, cleaning of human skeletons, historical and archaeological research of the object, archaeological and topographic measurements [5]. As a result, many materials of archaeological research were collected, and on the basis of these materials a monograph about the historical monument «Ishrathon» was written in 1958. In 1941, with the participation of 10 students in Samarkand, in 1942, archaeological research was conducted on the Shahrisabz cultural monuments.

In the issue of the expedition in 1943, historical and archaeological research was carried out in the "Gur Amir» mmausoleum with the aim of reading the tombstones of A.Temur, restoring the territory and the 
architecture of the mausoleum, and restoring the historical map of Samarkand.

During World War II, the department conducted research on products used in Central Asia as a substitute for sugar and tea, the origin of the Lakai horse breed, the ancient iron and steel industry in Uzbekistan and other historical topics.

In 1943-1944 he studied the mausoleum of "Yunuskhan" in Tashkent, and in 1945 he conducted an expedition with students to study the mausoleum of Manas Gumbazi in the Talas valley of Kyrgyzstan.

Also in 1946, under the leadership of M.E.Masson, a large-scale expedition was carried out in the Complex Archaeological Expedition of Southern Turkmenistan (UTAKE) with the participation of doctoral, graduate students and members of the department.

In 1947-1960, E.M. Masson and the staff of the department participated in a number of archaeological expeditions and projects in Bukhara, Toytepa, Parkent, Sukak, Chinoz, Zangiota, Termez and Tashkent. In 1958 the 6oth anniversary of the head of the department E.M. Masson was celebrated, where more than 200 research works were presented, more than 63 route maps of archaeological research were presented. In only 20 years the department has published more than 250 scientific works.

Department of Archaeology with the Institutes of History of Material Culture, Oriental Studies of the Academy of Sciences of the USSR, Institute of Language and Literature of the Academy of Sciences of the Uzbek SSR, Departments of Geography, Geology and Art of the Central Asian State University (now the National University of
Uzbekistan) and other organizations held discussions at the Scientific Council.

In addition, the members of the Department participated with presentations and research works at conferences of the Institute of History of Material Culture of the USSR Academy of Architecture of the USSR, Academy of Sciences of the UzSSR and Geographical Society of Uzbekistan, institutes of ethnography of the USSR Academy of Architecture. The original article provides complete information on the topics of the scientific presentations made by the members of the department at the conferences.

The article reports that over the years the range of disciplines taught in the department has expanded. For example, M. E. Masson has taught courses on "historical topography of the cities of Central Asia", "historical topography of Tashkent", "Central Asian numismatics", "introduction to the archaeology of Central Asia", "historical geography and topography of Tashkent oblast", "Study of the history of Central Asia from an archaeological point of view", as well Assistant Professor A.G.Pugachenkova lecture courses such as "History of architecture of Central Asia", "Monuments of architecture of Iran and Afghanistan", "Monuments of architecture of Tashkent", "Art of the East". At the initiative of the department, the teaching staff developed courses such as "Anthropogeography of Central Asia" (N.G. Malitsky), "Central Asian paleography", "Central Asian chronology and metrology" (A.A. Semenov), "Arts and crafts of Central Asia" ( A.S. Morozova), "Quaternary geology" (Ya.A. Skvortsov), "History of the Caliphs" (A.M. Matveev) [6].

The specialists of the department gave their scientific advice and recommendations to 
museum organizations of Uzbekistan, geological organizations, the department of museology of Moscow State University, the Institute of the History of Material Culture of the Academy of Sciences of the USSR, the Academy of Architecture of the USSR, the main gold mining administration of the USSR, the scientific research institute of animal husbandry of the USSR, the scientific research institute of horse breeding of the USSR, the Turkmen Institute of Language and Literature, the Turkmen State Museum, the Hermitage Museum, the Leningrad Museum, the Institute of Archeology and Art of the Academy of Sciences of the Azerbaijan SSR and others.

\section{ARCHIVAL DOCUMENTS FOUND IN THE PARTHIAN RUINS}

One of the most pressing issues in Central Asia today is the study of the activities and history of ancient archives. Today, there are practically no comprehensive studies on this topic.

E.M. Masson's personal collection also contains interesting articles about archival documents found as a result of archeological excavations in the Parthian ruins.

A copy of the article by I. M. Dyakonov, M. M. Dyakonov and V. A. Livshchits "New Findings of Parthian Documents" has been preserved in the 1125-archival file of the Foundation. The article was personally recommended for publication in 1952 in the first issue of Izvestia of the Academy of Sciences of the USSR for 1953 by E.M. Masson [7].

According to the state, in 1951 in the basement of the old Parthian ruin was found more than 140 archival documents, which were fixed on ceramics.
According to E.M. Masson, these documents were reporting documents of the winery dating back to the II century BC. Detailed information about these archival documents is given in the second archeological report of STACE [8] in 1951 by E.M.Masson, I.M.Dyakonov, M.M.Dyakonov and V.A.Livshchits [9].

As a result of an archaeological expedition, photocopies of 146 ceramic texts were obtained. Texts, inscriptions on some ceramics were removed. The report stated that 43 documents were in good condition and that these documents were in the nature of a letter and receipt from the recipient at the time. In ceramics, the Aramaic words "vinegar" and "grapes" are often used. The dates of the documents are from $131 \mathrm{BC}$. until 144 BC clearly preserved.

In conclusion, we can say that the personal fund R-2773 of M.E. Masson, stored today in the National Archives of Uzbekistan, contains important scientific research in archeology, numismatics, anthropology, historical geography, historical topography, historical chronology and metrology, historical architecture, anthropogeography, paleography of Central Asia, history of art craft, Quaternary geology, history of architectural monuments of Iran and Afghanistan.

Also, the archival documents of this fund are important in carrying out historical research on the problems of archeology, historical geography, topography, numismatics and archives of ancient times in Central Asia.

Evidence from existing records show that, the information in the documents is written in Parthian script based on Aramaic script. The 1126 collection of the EM Masson personal 
fund contains a copy of an article by IM Dyakonov and VA Livshchits, published in Moscow in 1960, entitled "Documents from
Nisy I veke do nashey ery," which analyzes the study of Parthian documents [10].

(Information on the approximate reading of the documents is provided. )

\section{II-43: 1. BHWT' $Z N H \quad M N \quad K R M '$ '[BZBRY] \\ 2. $M N$ 'RTBNWKN 'RTHSTRK[N $K]$ RY \\ 3. HM - IIII III II $\{[M N]$ PTPRHKK \\ 4. HN'LT. 'L ŚNT IC $\overline{X X X}-$ IIII HYTY \\ 5. [']RTWRŠT MRWBR ZY MN SYGBYŠ}

\section{CONCLUSION}

In conclusion it can be said that, the personal fund of M.E. Masson R-2773, which stored in the National Archives of Uzbekistan, is an important historical source on the history of archeology, numismatics, anthropology, historical geography, topography, chronology and metrology, historical architecture, anthropogeography, paleography of Central Asia.

The archival documents of this fund also play an important role in conducting historical researchs on the problems of historical geography, topography, numismatics and archeology of Central Asia.

As a result of archaeological expeditions conducted by archaeologists on the history of antiquity, it is possible to obtain accurate information about many archives of Central Asia.

\section{REFERENCES}

1. Decree of the President of the Republic of Uzbekistan dated September 20, 2019 № PF-5834 "On measures to improve archival work and record

keeping in the Republic of Uzbekistan"; Resolution of the President of the Republic of Uzbekistan dated 19.12.2018 No PP4068 "On measures to radically improve the activities in the field of protection of tangible cultural heritage"; Resolution of the Cabinet of Ministers of the Republic of Uzbekistan "On radical improvement of archaeological research" dated 21.09.2019.

2. National Archives of Uzbekistan, Fund R-2773, inventory -1 , the part of Introduction, page 1-5.

3. National Archives of Uzbekistan, Fund- R-2773, inventory -1, case -1240 . Page-1-36. "Department of Archeology of Central Asia SAGU 19401960 gg. Article. Mashinopisnaya kopiya s avtorskoy pravkoy. "1-36-str.

4. National Archives of Uzbekistan, Fund R-2773, inventory -1 , case -1240 , page $-1$. 
5. National Archives of Uzbekistan, Fund

R-2773, inventory -1 , case -1240 , page -2 .

6. National Archive of Uzbekistan, Fund

$\mathrm{R}-2773$, inventory -1 , case -1240 , page

$-12$.

7. National Archive of Uzbekistan, Fund2773, inventory-1, case -1225, page 1-3.

8. STACE- South Turkmenistan archaeological complex expedition (ЮТАКЭ - Южно-Туркменистанская археологическая комплексная экспедиция).

9. Masson Ye.M., D'yakonov I.M., Dyakonov M.M. i Livshchits V.A. “Materialy YUTAKE" . L-M., 1951.

10. National Archive of Uzbekistan, Fund2773, Inventory-1, case - 1226, page 1-3. 